\title{
Miracle in Cancer Care: A Transformative Bond
}

\begin{abstract}
The bond period after formal academic training is many times perceived by residents as an unnecessary barrier, which prevents them from a fabulous career ahead. In this article, a post-DM and post-MD resident shares their experience of bond period at a government cancer center in rural Vizag. They got an opportunity to witness the results of an outstanding vision and unwavering commitment in the field of oncology, especially in the context of lack of adequate infrastructure.
\end{abstract}

Keywords: Cancer care, Homi Bhabha Cancer Hospital and Research Centre Vizag, residency bond

\section{Introduction}

On the eve of 2019, my destiny landed me at Vizag, the City of Destiny. As part of the 1 -year bond that every medical oncology resident at Tata Memorial Centre (TMC), Mumbai has to complete after 3 years of DM course, I was at Vizag. From the shores of the Arabian Sea to the beaches of Bay of Bengal, the shift I thought will be just of the rooms. However, something much deeper awaited me at the Homi Bhabha Cancer Hospital and Research Centre (HBCHRC), the Vizag unit of TMC, Mumbai, under the Department of Atomic Energy, Government of India.

\section{The Soil}

In 2009, the Indian Government decided to establish new cancer centers in different nooks of the country in collaboration with TMC, Mumbai. Dr. Y. S, Rajasekhara Reddy, then chief minister of Andhra Pradesh accepted this opportunity. The first official team visited the site at Aganampudi, a village on the outskirts of Vizag, inhabited by the employees in Steel Plant and people working in the unorganized sector. About a hundred acres of barren land under the government was identified in the valley on the sides of the National Highway, NH 16. As it happens often, the official proceedings dragged on till 2013, when the land was finally registered under the hospital. There was no way that the

This is an open access journal, and articles are distributed under the terms of the Creative Commons Attribution-NonCommercial-ShareAlike 4.0 License, which allows others to remix, tweak, and build upon the work non-commercially, as long as appropriate credit is given and the new creations are licensed under the identical terms.

For reprints contact: WKHLRPMedknow_reprints@wolterskluwer.com hospital could offer any services in the near future as even the building tenders were not opened at that time.

\section{The Buds and Saplings}

In 2013, being a barren land, the hospital administration decided to plant saplings around. The initiative resulted in 4000 plants, which included mainly the Indian trees such as neem, peepul, mango, jamun, and banyan. Thus, even before the hospital started, the life energy expressed itself in full bloom here. The same energy infuses strength to scores of cancer patients who visit this place today. The area around the hospital today has one of the best green pastures among the oncology hospitals in the country.

\section{Garden and the Gardener}

"A Project Site under construction" would have been the obvious fate for years. However, in 2014, it was proposed that clinical services would begin inside a shipping container! Two shipping containers were painted blue and converted into outpatient units. Subsequently, few smaller buildings were built around the container to accommodate the increase in the patient numbers. The turning point for the institution happened when Dr. Raghunadharao Digumarti took over the post of director. As the Professor of Medical Oncology at Nizam's Institute of Medical Sciences, Hyderabad, he was well settled in the city with a busy clinical and administration schedule and numerous

\footnotetext{
How to cite this article: Mullapally SK, Jayasree L. Miracle in cancer care: A transformative bond. Indian J Med Paediatr Oncol 2020;41:51-3.
}

\section{Sujith Kumar} Mullapally', Lekshmy Jayasree ${ }^{2}$

${ }^{1}$ Department of Medical Oncology, Tata Memorial Centre, Homi Bhabha National Institute, Mumbai, Maharashtra, India, ${ }^{2}$ Department of Radiology, Tata Memorial Centre, Homi Bhabha National Institute, Mumbai, Maharashtra, India

Submitted: 26-Sep-2019 Revised: 10-Nov-2019 Accepted: 12-Nov-2019 Published: 24-Apr-2020

Address for correspondence: Dr. Sujith Kumar Mullapally, Departments of Medical Oncology, Tata Memorial Centre, Homi Bhabha National Institute, Mumbai,

Maharashtra, India.

E-mail: drsujithm@gmail.com

Access this article online

Website: www.ijmpo.org

DOI: 10.4103/ijmpo.ijmpo_201_19 Quick Response Code:

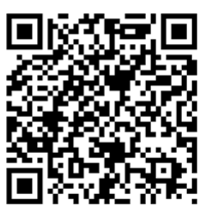


research projects. Armed only with zeal for human service and openness to face challenges, he solely started the medical oncology OPD on June 2, 2014, inside the shipping container. His years of clinical and administrative experience has since then reflected in the dynamic and decisive future course of the institution. Even today, the OPD runs inside a modified shipping container!

\section{The Blooming Flowers}

Apart from medical oncology services, the onus was first laid on the preventive and palliative care aspects, very essential for the rural population. From the beginning, the department of gyneconcology pioneered cervical cancer screening measures along with HPV vaccination efforts and currently coverage of services has steadily grown along with expertise in doing liquid-based cytology and HPV testing in the molecular oncology department inside the hospital. The HBCHRC conducted the annual meeting of Indian Society of Colposcopy and Cancer Pathology at Vizag in April 2019. It has also been selected by the ICMR recently as the nodal center for training all government health personnel and nongovernmental organizations in cervical cancer screening as per its ECHO programme.

Palliative care at the HBCHRC also began in a shipping container and now has expanded into all aspects of palliative care, including childhood cancer services, home visits, hospice, training, and education of the community. It conducts an IAPC certificate course in palliative care twice in a year. The onus is on early integration of palliative care in pediatric cancer patients at the HBCHRC, and the department work in this aspect won the first prize for poster in the annual Pediatric Solid Tumor Conference conducted by the TMC, Mumbai, in April 2019. Huddles for quick interdisciplinary meetings and collaborative alliances are unique to the palliative care practice here.

The daycare in the hospital provides chemotherapy to 30-40 patients per day every day and has been selected by the Tata Trusts as the model daycare center in the country for the training of oncology nurses. The medical oncology department successfully conducted the DNB Medical Oncology Practical examinations in May 2019. HBCHRC is the only cancer center in Vizag, which has a qualified pediatric oncologist for childhood cancer care. With the lack of facilities such as operation theater and intensive care unit (ICU) in the Aganampudi temporary hospital, the surgery unit was made possible by collaborating with the Visakhapatnam Port Hospital. The third floor of Port Hospital was renovated with the help of sponsors and handed over to the HBCHRC for oncosurgery, ICU, and inpatient services.

Equipped with basic imaging like X-rays, ultrasound apart from mammogram, the radiologists manage to do 5-10 interventions per day including biopsies, fine-needle aspiration cytology, cell block, pleural taps, etc., Recently, computed tomography (CT) has become functional since August 2019. Oncopathology department has grown to become the referral center for the examination of biopsies done from different hospitals in the district of Vizag and is also an accredited center for liquid-based cytology. Almost all immunohistochemistry tests are done in the unit. Molecular oncology unit is equipped with real-time polymerase chain reaction facility and routinely does molecular tests for CML, $\mathrm{HPV}$, etc., For a resident who trained in the best facilities of TMC, Mumbai, this is a wonder that all of this exists in makeshift buildings.

\section{The Deep Roots}

For HBCHRC, the roots derive nutrition from two sources: the hearts of benevolent sponsors and the support from TMC, Mumbai. The patient facilities such as the air-conditioned waiting hall, canteen hall, and water purifier are sponsored by different trusts and individuals. The transparency and sincerity in such transactions have motivated many to come forward to help. The HBCHRC is a unit of TMC, Mumbai, which supports the financial, academic, and administrative working of the institution. Resident doctors from TMC are posted in the departments of medical and surgical oncology, anesthesia, and radiology as a part of the bond and get an unparalleled chance to learn that limited infrastructure is not an impediment to quality cancer care. The infrastructure of the actual proposed hospital is being built up currently, and by the end of 2019, it is supposed to be fully functional with advanced imaging and radiation therapy facilities.

\section{A Resident's Awe}

From the midst of the complexity of CTs and magnetic resonance imaging at the $\mathrm{TMC}$, radiology residents come to the simplicity of HBCHRC, Vizag. These words from one of them beautifully capture the experience. "How monotonous will be a place which has only radiography, ultrasonography, and mammography units functioning since 3 years? That was the question everyone in my department back in Mumbai had. But I came here for a 3month term and realized this was everything opposite of monotonous. The variety of cases and the proportion of undiagnosed cases were ample here and that was a challenge which pushes one's intellect to the limits enriching the knowledge database. The faith that the seniors have in you and genuine encouragement and freedom to put forward your thoughts is humbling as well as boosts the confidence and puts a positive pressure to be worthy of it. The working environment here is admirable. Everyone's behavior here, including the nonteaching staff, is so cordial and welcoming that one never feels like an outsider, and is so beautifully accepted into the family." 


\section{Homi Bhabha Cancer Hospital and Research Centre: Miracle in Cancer Care}

HBCHRC is a miracle because, in any other instance or in any other part of our country, it would have been a paper entity from 2009 for the next 10 years. The proposed hospital building still is not complete or suitable for any clinical services. The authorities led by the Director himself took the initiative to start the oncology services to the needy patients in Vizag in 2014. Since then, more than 23,000 patients have been treated at this small temporary facility. Making a start inside a shipping container (where outpatient services still continue), it blissfully offers hope, cure and care to thousands of patient from Andhra Pradesh,
Orissa, and Jharkhand with the best treatment that can be received in any tier-one city or top oncology center in the country. This is a saga of magnificent vision, unwavering passion and impeccable service in oncology care in our country with limited resources. For a bonded resident, there is no better way to become transformed than this experience.

\section{Financial support and sponsorship}

Nil.

\section{Conflicts of interest}

There are no conflicts of interest. 